\title{
OBITUARIES
}

\section{Richard Bell}

Dr. Bell took the courses in arts and divinity at Edinburgh and then studied for a time in Germany. On his return he became assistant to the Professor of Hebrew at Edinburgh, where part of his duty was to teach Arabic; he also acted as examiner in divinity. He then became Minister of Wamphray, a country parish ; remaining there till he went back to Edinburgh in 1921, first as lecturer and then reader in Arabic. He retired at the age limit in 1947. His life was uneventful and it was not till a few years ago that he visited Arabic-speaking lands. A German professor said that if anyone was to complete Lane's lexicon, Bell was the man. His first idea was to devote himself to Arabic mathematics, working on the MSS. in the university library, but he gave that up and spent his life in the study of the Koran. The first-fruits of this were his Gunning lectures (1925), The Origin of Islam in its Christian Environment. The principles learned in the study of the Old Testament were applied to the Koran and in the lay-out of his translation Bell made it clear that it was a much-edited book and that the composition was more complicated than the Muslim authorities allowed. The orthodox will find it hard to explain away some of the facts to which Bell called attention. An Introduction to the Koran is in the press. Latterly his health was not good but he left his notes on the Koran ready for printing. His friends and pupils will remember him as a sound scholar who never thrust himself forward but was always ready to give a helping hand.

\section{A. S. Tritton.}

\section{H. L. Rabino di Borgomale}

H. L. Rabino, who was born on 27th July, 1877, and died on 26th September, 1950, contributed much to our knowledge of the history and geography of Persia. His father, manager of the Imperial Bank of Persia and a man of scholarly habits, directed his attention to Persian studies and at an early age he mastered the difficult art of Persian calligraphy and described a collection of Persian coins belonging to the Bank. His service in the Kermanshah branch of that institution (1903-5) was combined with consular duties in Persian Kurdistan, and he eagerly studied and wrote on the adminis- 
trative divisions of that governorship, and on the important problem of semi-nomad tribes, with their subdivisions and ruling families (reports of 1903-6). In 1906 he was transferred to the consular service and posted to Rasht where he spent six years, devoting his leisure to the study of the geography, history, inscriptions and industries of the Caspian provinces. Till the last days of his life he remained faithful to this early attachment. Expressing himself with equal facility in English and in French, he wrote a great number of books, articles, and reports on his travel impressions and on the geography and history of the southern coast of the Caspian.

In 1912 Rabino was appointed to Mogador (Morocco) where he became interested in the legal organization of the hubus (waqf "pious foundations"). After serving in Smyrna and Salonika he finished his career as Consul-General in Cairo (1929-37), but till 1947 the Foreign Office often took advantage of his experience.

L. H. Rabino had the excellent idea of inserting his own bibliography at the end of his book called Coins, Medals, and Seals of the Shähs of Iran (1509-1941), published by the Persian Government (London, 1945). After that he produced several other works, the last the very useful " Coins of the Jalā'ir, Kara koyunlu, Musha'sha" and Ak koyunlu dynasties" (which appeared posthumously in the Numismatic Chronicle, sixth series, vol. $\mathrm{x}, 1950$ ).

The best-known books by H. L. Rabino are "Les provinces caspiennes de la Perse. Le Guîlân", Revue du Monde Musulman, vol. xxxvii, 1916, and "Mazandaran and Astarabad", in the E. J. W. Gibb Memorial series, 1928. They will long remain sources of information, as also will his studies in the complicated genealogies of the rulers of the Caspian provinces (in JRAS. and the Journal Asiatique), and his last two numismatic surveys of Persian dynasties. It is a gratifying thought that amid multifarious official duties and despite indifferent health, H. L. Rabino could carry on his favourite studies with so much energy and perseverance.

V. MiNORSKY.

\section{R. E. Enthoven}

Mr. Reginald Edward Enthoven, C.I.E., who entered the Indian Civil Service in Bombay in the same year as Sir Charles Fawcett, died soon after him, on 21st May, 1952, being also in his eightythird year. Educated at Wellington and New College, Oxford, he 